\title{
Malaysian

\section{Virulence genes profile and biofilm formation of Methicillin-resistant and Methicillin-susceptible Staphylococcus aureus isolates from diabetic foot infections}

\author{
Sahd Ali*, Mustafa Bulent Ertugrul² and Bulent Bozdogan ${ }^{1,3}$ \\ ${ }^{1}$ REDPROM Research Center, Aydın Adnan Menderes University, 09100 Aydin, Turkey. \\ ${ }^{2}$ Infectious Disease Department, Medical Faculty, Aydın Adnan Menderes University, 09100 Aydin, Turkey. \\ ${ }^{3}$ Medical Microbiology Department, Medical Faculty, Aydın Adnan Menderes University, 09100 Aydin, Turkey. \\ Email: sahdali24@gmail.com
}

Received 10 February 2021; Received in revised form 5 April 2021; Accepted 2 June 2021

\begin{abstract}
Aims: Diabetic foot infections (DFIs) represent one of the most important risk factors for lower extremity amputation. One of the major infection agents that causes DFls is Staphylococcus aureus. Staphylococcus aureus is an important human pathogen causing variety of clinical manifestations which can lead to invasive infections, sepsis and even death. Outcomes of antibiotic treatment of diabetic foot infections may depend not only on the antimicrobial susceptibility of the etiological agents, but also their ability to produce diverse virulence factors. This study was aimed to investigate biofilm production and the presence of various virulence genes among Methicillin-resistant Staphylococcus aureus (MRSA) and Methicillin-susceptible Staphylococcus aureus (MSSA) isolates obtained from patients with DFls.

Methodology and results: A total of 48 clinical MRSA and MSSA isolates obtained from diabetic foot patients were studied for their biofilm formation and the presence of 29 known virulence genes. The biofilm formation was observed, analyzed and quantified using the microtiter plate method. Biofilm production was observed as $95.50 \%$ and $92.00 \%$ in the MRSA and MSSA isolates, respectively. Among the 29 virulence genes tested on the 48 clinical isolates, 19 virulence genes were detected. It was found that aap $(62.50 \%)$, etd $(54.17 \%)$, icaD $(50.00 \%)$, aae $(50.00 \%)$, seh $(31.25 \%)$ and icaADB (22.92\%) were the most prevalent genes. A total of 10 virulence genes (etb, gehD, icaB, icaC, seb, hla_haem, hld_epid, altE, fbe and sesl) were absent in all the isolates used.

Conclusion, significance and impact of study: Virulence genes play important role in clinical infections. Our results showed the presence rates of biofilm formation and accumulation-associated factors that are high among MRSA as well as MSSA isolates from DFIs. These results confirmed the importance of biofilm formation as regarded for DFls.
\end{abstract}

Keywords: MRSA (Methicillin-resistant Staphylococcus aureus), MSSA (Methicillin-susceptible Staphylococcus aureus), Diabetic foot infections (DFIs), virulence factors

\section{INTRODUCTION}

Diabetic foot infections (DFIs) are soft tissue or bone infections below the malleoli, representing one of the most important risk factors for lower-extremity amputation, substantial morbidity and resulting in high treatment cost (Lipsky et al., 2016). The pathophysiology of DFIs is complicated, relating to both host-disorders like neuropathy, arteriopathy and pathogen-related factors like virulence and antibiotic resistance (Dunyach-Remy et al., 2016). Bacteria causing DFIs normally differ based on the geographical region in which they are allocated. The aerobic Gram-positive cocci like Staphylococcus aureus are usually found in the North America and Europe, while in Africa and Asia are usually aerobic Gram-negative bacilli such as Pseudomonas aeruginosa (Hatipoglu et al., 2014). Staphylococcus aureus is among the first pathogens to be described in the clinical manifestation and it is still considered as one of the deadliest pathogens of humans. The exceptional level of $S$. aureus to possess various resistance against multiple antibiotic classes contributes to clinical complications of this pathogen, leading to difficulties in choosing appropriate antibiotics (Diekema et al., 2001; Schito, 2006).

Semisynthetic antibiotic methicillin was discovered in the 1950s, with methicillin-resistant $S$. aureus (MRSA) clinically identified in the 1960s (Bergdoll et al., 1981). MRSA strains produce penicillin-binding protein (PBP) with decreased affinity for most semisynthetic penicillin. This protein is encoded by $\operatorname{mec} A$ gene, which is carried on a mobile genetic element (MGE), designated Staphylococcal cassette chromosome mec (SCCmec) (Freer and Arbuthnott, 1982). Infections associated with MRSA strains results in high mortality rate than infections 
caused by methicillin-susceptible $S$. aureus (MSSA) strains (Liu et al., 2015). Among the multiple virulence factors produced by $S$. aureus is the production of cytotoxins, which includes hemolysins, staphylococcal enterotoxins, toxic-shock syndrome toxin-1 (tsst-1) and Panton-valentine leukocidin (Mariutti et al., 2017).

Toxins play important role in the pathogenicity of $S$. aureus by producing lesion directly or indirectly to the membrane of the targeted cells (Amagai et al., 2002). Staphylococcal enterotoxins (SE) are globular watersoluble proteins, rich in lysine, aspartic acid and glutamic acid with a molecular weight of $26-29 \mathrm{kDa}$. Enterotoxins are relatively resistant to heat and the presence of its proteolytic enzyme allows it to breach via gastro-intestinal tract during infections (Wolk et al., 2009). Biofilm serve as a key barrier interfering antimicrobial agents and host immune system during staphylococcal infections. Biofilm is a fundamental factor for chronic bacterial infections, which is composed of a cell-multilayer embedded in a slime matrix. Cell aggregation and biofilm accumulation are mediated by the composition of ica $A D B$ and ica $C$ genes, which is responsible for encoding essential proteins for the production of polysaccharide intercellular adhesion (PIA) and capsular polysaccharide/adhesion in Staphylococcus spp. (Katayama et al., 2000). Another important toxin is the Panton-valentine leukocidin (PVL), a pore-forming cytotoxin that causes destruction of human and rabbit mononuclear and polymorph nuclear cells (Bergdoll et al., 1971). Exfoliative toxins are also known as the epidermolytic toxins. They are specific serine proteases produced by $S$. aureus, which recognize and hydrolyze desmosome cadherin in the superficial layers of epidermis in humans. It causes cleavage of keratinocytes junction and cell-to-cell adhesion in the epidermis of the host cell, leading to peeling and blistering of the skin (Cramton et al., 1999; Prévost et al., 2001).

The evaluation and correlation between specific virulence genotypic markers in $S$. aureus isolates from DFIs has being studied on various dimensions. It is reported that Staphylococci is the virulent pathogen that is most frequent identified in clinical isolates in DFls (Lipsky et al., 2016). Recently, due to the increase in multi-drug resistant (MDR) isolates, the complications of DFIs have increased rapidly which makes it difficult to differentiate true infectious pathogens from colonizers (Spichler et al., 2015). The clinical importance of bacterial virulence factors is related to whether or not they are expressed, and if expression leads to increase virulence. In this regard, several molecular studies have been performed to detect virulence factors responsible for Staphylococcal pathogenicity in relation to wound adherence and colonization (Sotto et al., 2008; Liesse lyamba et al., 2011; Víquez-Molina et al., 2018). In this study, we aimed to investigate the ability of biofilm production and the presence of various virulence factor genes among MRSA and MSSA isolates cultured from patients with DFIs in Turkey.

\section{MATERIALS AND METHODS}

\section{Bacterial isolates}

A total of $48 \mathrm{~S}$. aureus isolates from diabetic foot infections were included in the present study. The isolates were obtained from routine clinical microbiology laboratory collection of Aydın Adnan Menderes University Hospital, Turkey. All samples were from the debridement material of diabetic foot wound infections. MRSA and MSSA represent 23 and 25 of the total 48 isolates, respectively. The isolates were grown aerobically on Tryptic Soy Agar (TSA) for $18-24 \mathrm{~h}$ at $37^{\circ} \mathrm{C}$ and stored in $2 \times$ skimmed milk at $-20^{\circ} \mathrm{C}$.

For PCR setup, $S$. aureus G3959 was served as positive control to identify hld_epid, gehD, icaA, icaB, icaC, icaD, hlb epid, atlE, fbe, aae, aap, gehC and sesl genes. While $\bar{S}$. aureus G4005 used to identify she and hla haem genes. These strains were received from clinical microbiology laboratory collection, Aydın Adnan Menderes University Hospital, Turkey.

\section{Observation of hemolysis}

To investigate the ability of the isolates to perform hemolysis, all the isolates were streaked on blood agar medium composed of Luria Bertani agar: 1.0\% tryptone (Merck Laboratory), $0.5 \%$ yeast extract (Merck Laboratory), $\quad 1.0 \% \quad \mathrm{NaCl}$ (Merck Laboratory), supplemented with pre-warmed $\left(37{ }^{\circ} \mathrm{C}\right) 5 \%$ sheep erythrocytes (bioMérieux, Ca. No. 55822). The plates were incubated at $37{ }^{\circ} \mathrm{C}$ overnight and the presence or absence of hemolysis was accessed based on the hemolytic zones produced (Figure 1).

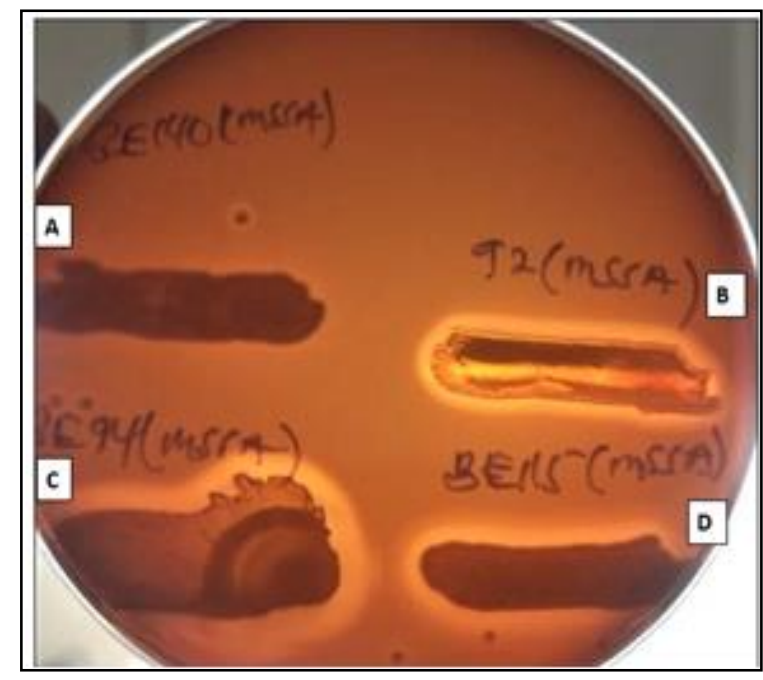

Figure 1: Hemolysis on blood agar. Hemolytic reaction of four isolates tested on sheep blood agar after $24 \mathrm{~h}$. Hemolysis; positive for 3 isolates ( $B, C$ and $D$ ) and negative for 1 isolate $(A)$. 


\section{Microtiter plate assay for biofilm formation}

The microtiter assay was used to evaluate the biofilm formation of MRSA and MSSA isolates as described previously (Stepanović et al., 2007). Briefly, bacteria were inoculated into TSB containing $0.25 \%$ glucose and incubated at $37{ }^{\circ} \mathrm{C}$ overnight. The overnight cultures were then diluted in 1:100 TSB with $0.25 \%$ glucose. Then, 200 $\mu \mathrm{L}$ of the overnight culture was transferred to $\mathrm{U}$-shaped 96 well micro plates and incubated for $48 \mathrm{~h}$ at $37^{\circ} \mathrm{C}$. For negative control, fresh TSB medium was used. Following incubation, the wells were discarded and gently washed three times with $200 \mu \mathrm{L}$ sterile phosphate buffered saline (PBS; pH 7.4). Biofilms were fixed dried at $60{ }^{\circ} \mathrm{C}$ for 45 min. Subsequently, plates were stained by adding $125 \mu \mathrm{L}$ of $1 \%$ crystal violet and incubated at room temperature for $15 \mathrm{~min}$. Excess crystal violet was rinsed under running water and left to ambient temperature to be dried. To dissolve any remaining stain, $150 \mu \mathrm{L}$ of $80 \%(\mathrm{v} / \mathrm{v})$ ethanol with $20 \%(\mathrm{v} / \mathrm{v})$ acetone was added.

The optical density (OD) of each well was measured spectrophotometrically at $595 \mathrm{~nm}\left(\mathrm{~A}_{595}\right)$ using the microplate reader (Thermo Multiscan Spectro). The negative control containing uninoculated TSB was used to determine the background OD. Formation of biofilms by MRSA and MSSA were analyzed and categorized depending on the absorbance of slime cells attached to crystal violet as described previously (Ohadian et al., 2014). The OD 595 values less than 0.125 were grouped as non-biofilm producers, those between $0.125-0.250(2 \times$ $0.125)$ as weak biofilm producers; between 0.250-0.5 (4 $\times$ $0.125)$ as moderate biofilm producers, and values higher than $1.0(8 \times 0.125)$ were considered as strong biofilm producers.

\section{Extraction of DNA for Polymerase Chain Reaction (PCR)}

All isolates were cultured aerobically on Tryptic Soy Agar (TSA) at $37{ }^{\circ} \mathrm{C}$ overnight. The DNA was extracted using DNA4PCR kit ( $R$ Tech Aydin, Turkey) protocol as recommended by the manufacturer. Briefly, 1 or 2 bacterial colonies were homogenized in $1 \mathrm{~mL}$ distillated water and centrifuged for $5 \mathrm{~min}$ at $13000 \mathrm{rpm}$. The supernatant was discarded, and pellet was resuspended in $100 \mu \mathrm{L}$ of DNA4PCR solution. The mixture was incubated at $56^{\circ} \mathrm{C}$ for $20 \mathrm{~min}$, vortexed and incubated at $100{ }^{\circ} \mathrm{C}$ for $10 \mathrm{~min}$. After vortexing for $15 \mathrm{sec}$ and centrifugation at $4{ }^{\circ} \mathrm{C}, 13000 \mathrm{rpm}$ for $5 \mathrm{~min}, 1 \mu \mathrm{L}$ of the supernatant was used for PCR. The purified DNAs were stored at $-20^{\circ} \mathrm{C}$ until use.

\section{Detection of virulence genes by PCR}

The presence of virulence genes: eta, etb, etd, etx, tst, luk-pvl, hla_haem, hlb_epid, hld_epid, icaA, icaB, icaC, icaD, ica $\bar{A} \overline{D B}$, gehD, sea, seb, sec, sed, see, seg, seh, sei, atIE, fbe, aae, aap, gehC and ses/ from the isolates of MRSA and MSSA were determined using PCR with the oligonucleotide primers as given in Table 1. The PCR was performed in a final volume of $50 \mu \mathrm{L}$ reaction mixture containing: 1× Taq buffer with $\mathrm{Mg}^{2+}, 0.2 \mathrm{mM}$ dNTP, 0.4 pmol forward primer and 0.4 pmol reverse primer, $1.5 \mathrm{U}$ Taq polymerase and $1.0 \mu \mathrm{L}$ purified DNA. PCR program was performed with an initial denaturing step at $95^{\circ} \mathrm{C}$ for $3 \mathrm{~min}$, followed by 35 cycles of denaturing at $95^{\circ} \mathrm{C}$ for 30 $\mathrm{sec}$, annealing at $50^{\circ} \mathrm{C}$ for $30 \mathrm{sec}$, extension at $72^{\circ} \mathrm{C}$ for $1 \mathrm{~min}$ and the reaction was finalized with an extension step at $72{ }^{\circ} \mathrm{C}$ for $5 \mathrm{~min}$. The PCR product $(5 \mu \mathrm{L})$ were mixed with $1 \mu \mathrm{L}$ of loading dye solution and carefully loaded into the $2 \%$ agarose gel well. The lambda Pstl marker (Thermo fisher Scientific, USA) was used to approximate the size of the amplicons. The gel was then electrophoresed at $100 \mathrm{~V}$ for $30 \mathrm{~min}$ and visualized under UV trans-illuminator device (Vilber Lourmat 08-200229).

\section{RESULTS AND DISCUSSION}

Despite the development of diverse control measures, bacterial infections remain among the leading causes of death among wound patients. Challenges in the treatment of staphylococcal infections are accompanied by several mechanisms of biofilm formation relating to this bacterium (Ohadian et al., 2014).

A total of $48 \mathrm{~S}$. aureus isolates from DFls among which 23 (48\%) MRSA and 25 (52\%) MSSA were studied. The ability of bacteria to produce biofilm was tested using the microtiter plate assay. Based on our results (Table 2 ), $16(69.5 \%)$ MRSA isolates were examined as moderate biofilm producer. Non-biofilm was formed by $1(4.3 \%)$ of MRSA isolates, $2(8.6 \%)$ of the MRSA isolates formed weak biofilm and $4(17.4 \%)$ of the MRSA isolates were considered as strong biofilm producers. On the other hand, among the 25 MSSA isolates, $15(60.0 \%)$ isolates were examined as moderate biofilm producer. Non-biofilm producer was recorded by $2(8.0 \%)$ of the MSSA isolates, $1(4.0 \%)$ of MSSA isolates as weak biofilm producer, whilst $7(28.0 \%)$ of the MSSA isolates formed strong biofilms. Smith et al. (2008) examined the biofilm formation of 763 (53.8\%) MRSA and 209 (43.5\%) MSSA isolates and they found that $20.5 \%$ of the MRSA and $28.0 \%$ of the MSSA isolates established fully established biofilm. O'Neill et al. (2007) documented similar study of biofilm formation in 114 clinical isolates of MRSA and found that only $9 \%$ had the ability to form fully established biofilms (strong biofilm producers). These differences in biofilm formation may be due to the variation in isolation site or the geographical differences in the isolated genotypes of the strains included in the study.

Virulence genes investigation among the isolates of MRSA and MSSA is presented in Table 3. From the 29 virulence genes tested, our results showed the presence of 19 virulence genes and absence of 10 virulence genes (etb, gehD, icaB, icaC, seb, hla_haem, hld_epid, altE, fbe and sesl) in all the isolates with the primers used. The virulence genes detected were eta, etd, etx, sea, sec, sed, see, seg, seh, sei, icaA, icaD, icaADB, aae, aap, luk_pvl, tst, hlb_epid and gehC. The most prevalent 
Malays. J. Microbiol. Vol 17(4) 2021, pp. 369-379 DOI: http://dx.doi.org/10.21161/mjm.211113

Table 1: Primer sequences used in the PCR assays for detecting virulence genes among the MRSA and MSSA isolates.

\begin{tabular}{|c|c|c|c|c|}
\hline Gene & Primer & Nucleotide sequence (5'-3') & $\begin{array}{l}\text { Product size } \\
\text { (bp) }\end{array}$ & References \\
\hline \multirow[t]{2}{*}{ ica $A$ (intercellular adhesion $\mathrm{A}$ ) } & forward & ACAGTCGCTACGAAAAGAAA & 103 & (Arciola et al., 2005) \\
\hline & reverse & GGAAATGCCATAATGAGAAC & & \\
\hline \multirow[t]{2}{*}{ icaB (intercellular adhesion B) } & forward & CTGATCAAGAATTTAAATCACAAA & 302 & (Arciola et al., 2005) \\
\hline & reverse & AAAGTCCCATAAGCATATGTTT & & \\
\hline \multirow[t]{2}{*}{ icaC (intercellular adhesion C) } & forward & TAACTTTAGGCGCATATGTTT & 400 & (Arciola et al., 2005) \\
\hline & reverse & TTCCAGTTAGGCTGGTATTG & & \\
\hline \multirow[t]{2}{*}{ icaD (intercellular adhesion D) } & forward & ATGGTCAAGCCCAGAGAG & 198 & (Arciola et al., 2005) \\
\hline & reverse & CGTGTTT TCAACATTTAATGCAA & & \\
\hline \multirow[t]{2}{*}{ icaADB (intercellular adhesion ADB) } & forward & TTATCAATGCCGCAGTTGTC & 546 & (Arciola et al., 2005) \\
\hline & reverse & GTTTAACGCGAGTGCGCTAT & & \\
\hline \multirow[t]{2}{*}{ aap (accumulation-associated protein) } & forward & ATACAACTGGTGCAGTGGTTG & 400 & (Vandecasteele et al., 2003) \\
\hline & reverse & GTAGCCGTCCAAGTTTTACCAG & & \\
\hline \multirow{2}{*}{$\begin{array}{l}\text { aae (surface associated protein and } \\
\text { autolysin) }\end{array}$} & forward & GAGGAGGATTTTAAAGTGC & 858 & (Heilmann et al., 2003) \\
\hline & reverse & AACATGACCATAGTAACC & & \\
\hline \multirow{2}{*}{ sea (enterotoxin A) } & forward & TTGGAAACGGTTAAAACGAA & 120 & (Johnson et al., 1991) \\
\hline & reverse & GAACCTTCCCATCAAAAACA & & \\
\hline \multirow[t]{2}{*}{ seb (enterotoxin B) } & forward & TCGCATCAAACTGACAAACG & 478 & (Johnson et al., 1991) \\
\hline & reverse & GCAGGTACTCTATAAGTGCC & & \\
\hline \multirow[t]{2}{*}{$\sec ($ enterotoxin $\mathrm{C})$} & forward & GACATAAAAGCTAGGAATTT & 257 & (Johnson et al., 1991) \\
\hline & reverse & AAATCGGGATTAACATTATCC & & \\
\hline \multirow[t]{2}{*}{ sed (enterotoxin D) } & forward & CTAGTTTGGTAATATCTCCT & 317 & (Johnson et al., 1991) \\
\hline & reverse & TAATGCTATATCTTATAGGG & & \\
\hline \multirow[t]{2}{*}{ see (enterotoxin E) } & forward & CAAAGAAATGCTTTAAGCAATCTTAGGCCAC & 170 & (Mehrotra et al., 2000) \\
\hline & reverse & CTTACCGCCAAAGCTG & & \\
\hline seg (enterotoxin $\mathrm{G})$ & $\begin{array}{l}\text { forward } \\
\text { reverse }\end{array}$ & $\begin{array}{l}\text { AATTATGTTGAATGCTCAACCCGATC } \\
\text { AAACTTATATGGAACAAAAGGTACTAGTTC }\end{array}$ & 642 & (Omoe et al., 2002) \\
\hline \multirow[t]{2}{*}{ seh (enterotoxin $\mathrm{H}$ ) } & forward & САATCACATCATATGCGAAAGCAG & 376 & (Omoe et al., 2002) \\
\hline & reverse & CATCTACCCAAACATTAGCACC & & \\
\hline sei (enterotoxin I) & forward & CTCAAGGTGATATTGGTGTAGG & 576 & (Omoe et al., 2002) \\
\hline
\end{tabular}


Malays. J. Microbiol. Vol 17(4) 2021, pp. 369-379 DOI: http://dx.doi.org/10.21161/mjm.211113

(Continued)

\begin{tabular}{|c|c|c|c|c|}
\hline & reverse & AAAAAACTTACAGGCAGTCCATCTC & & \\
\hline \multirow[t]{2}{*}{ tsst-1 (toxic shock syndrome toxin-1) } & forward & AGCATCTACAAACGATAATATAAAGG & 481 & (Seier-Petersen et al., 2015) \\
\hline & reverse & CATTGTTATTTTCCAATAACCACCCG & & \\
\hline \multirow[t]{2}{*}{ eta (exfoliative toxin A) } & forward & CTATTTACTGTAGGAGCTCTCTAT & 741 & (Amagai et al., 2002) \\
\hline & reverse & ATTTATTTGATGCTCTCTAT & & \\
\hline \multirow[t]{2}{*}{ etb (exfoliative toxin B) } & forward & ATACACACATTACGGATAAT & 629 & (Amagai et al., 2002) \\
\hline & reverse & CAAAGTGTCTCCAAAAGTAT & & \\
\hline \multirow[t]{2}{*}{ etd (exfoliative toxin D) } & forward & AACTATCATGTATCAAGG & 376 & (Amagai et al., 2002) \\
\hline & reverse & CAGAATTTCCCGACTCAG & & \\
\hline \multirow[t]{2}{*}{ etx (exfoliative toxin $\mathrm{X}$ ) } & forward & TACTCATACTGTGGGAACTTCGATACAAGC & 403 & (Amagai et al., 2002) \\
\hline & reverse & СТСАТСТСССАТААСТGСАСТАТААТTTCG & & \\
\hline \multirow{2}{*}{$\begin{array}{l}\text { luk pvl (pore forming toxin, Panton } \\
\text { valentine leukocidin) }\end{array}$} & forward & ATCATTAGGTAAAATGTCTGGACATGATCCA & 433 & (Lina et al., 1999) \\
\hline & reverse & GCATCAATGTATTGGATAGCAAAAGC & & \\
\hline \multirow{2}{*}{$\begin{array}{l}\text { at/E (attachment to polystyrene and } \\
\text { vitronectin) }\end{array}$} & forward & CAACTGCTCAACCGAGAACA & 682 & (Vandecasteele et al., 2003) \\
\hline & reverse & TTTGTAGATGTTGTGCCCA & & \\
\hline gehC (Lipase binding to collagen) & $\begin{array}{l}\text { forward } \\
\text { reverse }\end{array}$ & $\begin{array}{l}\text { CAAAAGATAGCCAATCAACAG } \\
\text { GCGTACAATCGCTTGTTACC }\end{array}$ & 700 & (Bowden et al., 2002) \\
\hline \multirow[t]{2}{*}{ gehD (Triacylglycerol lipase D) } & forward & TTTGAATTCTGCAAGCTCAATATAA & 1179 & (Bowden et al., 2002) \\
\hline & Reverse & TTTGCGGCCGCTATCGCTACTTACGTGTAA & & \\
\hline \multirow[t]{2}{*}{ sesl (surface binding protein) } & forward & GCTGATTATGTAAATGACTCAAAT & 408 & (Johnson et al., 1991) \\
\hline & Reverse & AGCTTTTGTTGTTTGAGCTTC & & \\
\hline \multirow[t]{2}{*}{ hla_haem (alpha hemolysin ) } & forward & TGGGCCATAAACTTCAATCGC & 72 & (Rosec and Gigaud, 2002) \\
\hline & reverse & ACGCCACCTACATGCAGATTT & & \\
\hline \multirow[t]{2}{*}{ hlb_epid (beta hemolysin) } & forward & TGGTGGCGTTGGTAT & 335 & (Rosec and Gigaud, 2002) \\
\hline & reverse & ACCCCAAGATTCAC & & \\
\hline \multirow[t]{2}{*}{ hld_epid (delta hemolysin) } & forward & TGGTGGCGTTGGTATTGTGA & 541 & (Rosec and Gigaud, 2002) \\
\hline & reverse & ACCCCAAGATTTCACGGACC & & \\
\hline \multirow[t]{2}{*}{ fbe (fibrinogen binding protein) } & forward & TAAACACCGACGATAATAACCAAA & 495 & (Arciola et al., 2004) \\
\hline & reverse & GGTCTAGCCTTATTTTCATATTCA & & \\
\hline
\end{tabular}


Malays. J. Microbiol. Vol 17(4) 2021, pp. 369-379

DOI: http://dx.doi.org/10.21161/mjm.211113

Table 2: Results of biofilm formation of MRSA and MSSA isolates in the presence of $0.25 \%$ glucose using the microtiter plate technique.

\begin{tabular}{|c|c|c|c|c|}
\hline & \multicolumn{4}{|c|}{ Biofilm formation } \\
\hline & $\begin{array}{c}\text { Non-biofilm } \\
\text { producer }^{\mathrm{A}} \\
\text { (ODs } \leq 0.125) \\
\mathrm{N}(\%) \\
\end{array}$ & $\begin{array}{c}\text { Weak biofilm } \\
\text { producer }^{\mathrm{B}} \\
(0.125<\text { ODs } \leq 0.25) \\
\mathrm{N}(\%)\end{array}$ & $\begin{array}{c}\text { Moderate biofilm } \\
\text { producerc } \\
(0.25<\text { ODs } \leq 0.50) \\
N(\%)\end{array}$ & $\begin{array}{c}\text { Strong biofilm } \\
\text { producerD } \\
(1.0<\text { ODs }) \\
\mathrm{N}(\%) \\
\end{array}$ \\
\hline $\operatorname{MRSA}(n=23)$ & $1(4.3)$ & $2(8.6)$ & $16(69.5)$ & $4(17.4)$ \\
\hline MSSA $(n=25)$ & $2(8.0)$ & $1(4.0)$ & $15(60.0)$ & $7(28.0)$ \\
\hline
\end{tabular}

${ }^{\mathrm{A}} \mathrm{ODs} \leq \mathrm{ODc} ;{ }^{\mathrm{B}} \mathrm{ODc}<\mathrm{ODs} \leq 2 \times$ ODc; ${ }^{\mathrm{C}} \mathrm{ODc}<\mathrm{ODs} \leq 4 \times \mathrm{ODc}^{\mathrm{D}} 1.0<\mathrm{ODs}$

$\mathrm{ODc}=$ Optical density at $595 \mathrm{~nm}$ of negative control

ODs = Optical density at $595 \mathrm{~nm}$ of samples

genes among the isolates were aap $(62.50 \%)$, followed by etd $(54.17 \%)$, icaD $(50.00 \%)$, aae $(50.00 \%)$, seh (31.25\%), icaADB (22.92\%), sei (18.75\%), gehC $(16.67 \%)$, see $(10.42 \%)$, icaA $(8.33 \%)$, sea $(6.25 \%)$, seg $(6.25 \%)$, sec $(4.17 \%)$, sed $(4.17 \%)$, eta $(4.17 \%)$, etx (4.17\%), luk_pvl (4.17\%), hlb_epid (2.08\%) and tst-1 $(2.08 \%)$. We also found that among the MRSA isolates; aae, aap and icaD genes were significant while etd, ica $A D B$ and gehC were significantly frequent in the MSSA isolates. These results indicate the presence of distinct virulence genes among MRSA and MSSA strains.

Staphylococci devote significant amount of energy to the production of virulence factors to protect the bacteria from host immune surveillance, and also promote the bacterial survive in hostile environment (Richard et al., 2011). Clinical outcome of $S$. aureus infections is influenced by the presence of various virulence genes. In this study, we found that MRSA and MSSA strains isolated from DFls were characterized by a high prevalence of biofilm formation (icaD, icaADB), biofilm production (aap), autolysin (aae) and exfoliative (etd) genes, whereas low frequency of other toxin genes (tsst1, luk_pvl and hlb_epid).

Biofilm formation contributes to the attachment of microbial cells to surfaces contributing to the initial stage of infections. It is considered as a characteristic virulence factor used by microbial organisms in pathogenesis enabling it to survive adverse environments within the host (Mashouf et al., 2015). Among these virulence genes responsible for biofilm is the icaD gene which encodes the $\mathrm{N}$-acetylglucosaminyl transferase; an enzyme involved in the synthesis of $\mathrm{N}$-acetylglucosamine oligomers from UDP-N-acetylglucosamine (Costerton et al., 1999). The prevalence of icaD gene in our study was $50.0 \%$ from the total isolates. MRSA and MSSA isolates displayed $60.0 \%$ and $40.0 \%$, respectively. This result is in accordance to the study of Ghasemian et al. (2016), which reported the presence of icaD gene with a frequency of (69.0\%) MRSA and (54.0\%) MSSA in 209 clinical isolates tested. Aggarwal et al. (2019) also documented the presence of icaD gene in 109 isolates from wound infections with a higher frequency in both MRSA (81.3\%) and MSSA (84.4\%). The activation of accumulation associated protein (aap) is controlled by bacterial and host-accompanied proteases (Conlon et al., 2014). In our study, the frequency of aap gene was $62.5 \%$, which MRSA and MSSA accounted for $69.5 \%$ and $56.0 \%$, respectively. These results emphasized the relationship between bio-film formations and adhesive mechanism during infections. The relationship between biofilm formation and aap gene had been studied largely in S. epidermidis (Schaeffer et al., 2015; Salgueiro et al., 2017; Guo et al., 2019), but not in $S$. aureus isolates.

Superantigens play essential role in the inflammations that occur in DFls. Staphylococcal enterotoxins are important superantigens causing non-specific activation of the immune system especially the T cells. However, they do not all involved in food poisoning. The important food poisoning toxins are encoded by sea, seb, sec, sed and see genes. More recently, it was found enterotoxin genes show superantigenic effect but not emetic effect (Omoe et al., 2002), except seh gene which is associated with food poisoning outbreak with raw milk (Jørgensen et al., 2005). In our study, seh gene was more frequently identified in $(39.10 \%)$ MRSA isolates, whereas sei gene was in the (32.00\%) MSSA isolates. In contrast, Sila et al. (2009) reported the absence of seh gene in all the MRSA and MSSA isolates from the 200 clinical samples (mostly skin and wound) tested. The frequency of seb gene reported in Gorgan, Iran (Kamarehei et al., 2013), Canada (Mehrotra et al., 2000) and Tehran (Norouzi et al., 2012) from the clinical samples were $61.3 \%, 15.8 \%$ and $73.6 \%$, respectively. However, none of the MRSA and MSSA isolates harbored the seb gene from our study. These differences may be due to the existence of different genotypes among the strains and the toxin profile of specific isolates which are affected by the origins of their geographical location (Moore and Lindsay, 2001).

Another important gene observed in our study was the exfoliative genes. Four staphylococcal exfoliative toxins, eta, etb, etd and etx were tested in this study. Our result showed a high frequency rate of etd gene in MSSA $(84.00 \%)$ isolates. In contrary, the etd gene was not found in any of the MSSA clinical isolates tested by (Wu et al., 2011). The etb gene was not detected in our study. Similarly, Peacock et al. (2002) did not detect etb gene in all the isolates tested. Moreover, the frequency of eta gene $(4.17 \%)$ was low in our study. Our results coincide 
Malays. J. Microbiol. Vol 17(4) 2021, pp. 369-379

DOI: http://dx.doi.org/10.21161/mjm.211113

Table 3: Number of virulence genes of MRSA $(n=23)$ and MSSA $(n=25)$ isolates from diabetic foot infections (DFIs).

\begin{tabular}{|c|c|c|c|c|c|c|c|}
\hline Gene group & $\begin{array}{l}\text { Virulence } \\
\text { genes }\end{array}$ & $\begin{array}{c}\text { Total } \\
\text { positive }\end{array}$ & $\begin{array}{c}\text { Positive } \\
\text { MRSA }\end{array}$ & $\begin{array}{c}\text { Positive } \\
\text { MSSA }\end{array}$ & $\begin{array}{c}\text { Positive MRSA } \\
(\%)\end{array}$ & $\begin{array}{c}\text { Positive MSSA } \\
\text { (\%) }\end{array}$ & $\begin{array}{c}\text { Total positive } \\
(\%)\end{array}$ \\
\hline Biofilm formation & $\begin{array}{c}i c a A \\
i c a B \\
i c a C \\
i c a D \\
i c a A D B\end{array}$ & $\begin{array}{c}4 \\
0 \\
0 \\
24 \\
11\end{array}$ & $\begin{array}{c}0 \\
0 \\
0 \\
14 \\
1\end{array}$ & $\begin{array}{c}4 \\
0 \\
0 \\
10 \\
10\end{array}$ & $\begin{array}{c}0 \\
0 \\
0 \\
60.00 \\
4.35\end{array}$ & $\begin{array}{c}16.00 \\
0 \\
0 \\
40.00 \\
40.00\end{array}$ & $\begin{array}{c}8.33 \\
0 \\
0 \\
50.00 \\
22.92\end{array}$ \\
\hline Biofilm production & aap & 30 & 16 & 14 & 69.50 & 56.00 & 62.50 \\
\hline Enterotoxins & $\begin{array}{l}\text { sea } \\
\text { seb } \\
\text { sec } \\
\text { sed } \\
\text { see } \\
\text { seg } \\
\text { seh } \\
\text { sei }\end{array}$ & $\begin{array}{c}3 \\
0 \\
2 \\
2 \\
5 \\
3 \\
15 \\
9\end{array}$ & $\begin{array}{l}3 \\
0 \\
1 \\
1 \\
4 \\
0 \\
9 \\
1\end{array}$ & $\begin{array}{l}0 \\
0 \\
1 \\
1 \\
1 \\
3 \\
6 \\
8\end{array}$ & $\begin{array}{c}13.00 \\
0 \\
4.35 \\
4.35 \\
17.40 \\
0 \\
39.10 \\
4.35\end{array}$ & $\begin{array}{c}0 \\
0 \\
4.00 \\
4.00 \\
4.00 \\
12.00 \\
24.00 \\
32.00\end{array}$ & $\begin{array}{c}6.25 \\
0 \\
4.17 \\
4.17 \\
10.42 \\
6.25 \\
31.25 \\
18.75\end{array}$ \\
\hline Hemolysin toxins & $\begin{array}{l}\text { hla_haem } \\
\text { hlb_epid } \\
\text { hld_epid }\end{array}$ & $\begin{array}{l}0 \\
1 \\
0\end{array}$ & $\begin{array}{l}0 \\
0 \\
0\end{array}$ & $\begin{array}{l}0 \\
1 \\
0\end{array}$ & $\begin{array}{l}0 \\
0 \\
0\end{array}$ & $\begin{array}{c}0 \\
4.35 \\
0\end{array}$ & $\begin{array}{c}0 \\
2.08 \\
0\end{array}$ \\
\hline Fibrinogen binding & fbe & 0 & 0 & 0 & 0 & 0 & 0 \\
\hline Lipase binding to collagen & $\begin{array}{l}\text { gehC } \\
\text { gehD }\end{array}$ & $\begin{array}{l}8 \\
0\end{array}$ & $\begin{array}{l}0 \\
0\end{array}$ & $\begin{array}{l}8 \\
0\end{array}$ & $\begin{array}{l}0 \\
0\end{array}$ & $\begin{array}{c}32.00 \\
0\end{array}$ & $\begin{array}{c}16.67 \\
0\end{array}$ \\
\hline Autolysin & $\begin{array}{l}\text { aae } \\
\text { altE }\end{array}$ & $\begin{array}{c}24 \\
0\end{array}$ & $\begin{array}{c}15 \\
0\end{array}$ & $\begin{array}{l}9 \\
0\end{array}$ & $\begin{array}{c}65.20 \\
0\end{array}$ & $\begin{array}{c}36.00 \\
0\end{array}$ & $\begin{array}{c}50.00 \\
0\end{array}$ \\
\hline Surface protein I & sesl & 0 & 0 & 0 & 0 & 0 & 0 \\
\hline Exfoliative toxins & $\begin{array}{l}\text { eta } \\
\text { etb } \\
\text { etd } \\
\text { etx }\end{array}$ & $\begin{array}{c}2 \\
0 \\
26 \\
2\end{array}$ & $\begin{array}{l}1 \\
0 \\
5 \\
1\end{array}$ & $\begin{array}{c}1 \\
0 \\
21 \\
1\end{array}$ & $\begin{array}{c}4.35 \\
0 \\
21.70 \\
4.35\end{array}$ & $\begin{array}{c}4.00 \\
0 \\
84.00 \\
4.00\end{array}$ & $\begin{array}{c}4.17 \\
0 \\
54.17 \\
4.17\end{array}$ \\
\hline$\beta$-pore-forming toxins syndrome toxin- 1 & luk_pvl & 2 & 2 & 0 & 8.70 & 0 & 4.17 \\
\hline Toxic-shock syndrome toxin & tsst-1 & 1 & 0 & 1 & 4.35 & 0 & 2.08 \\
\hline
\end{tabular}




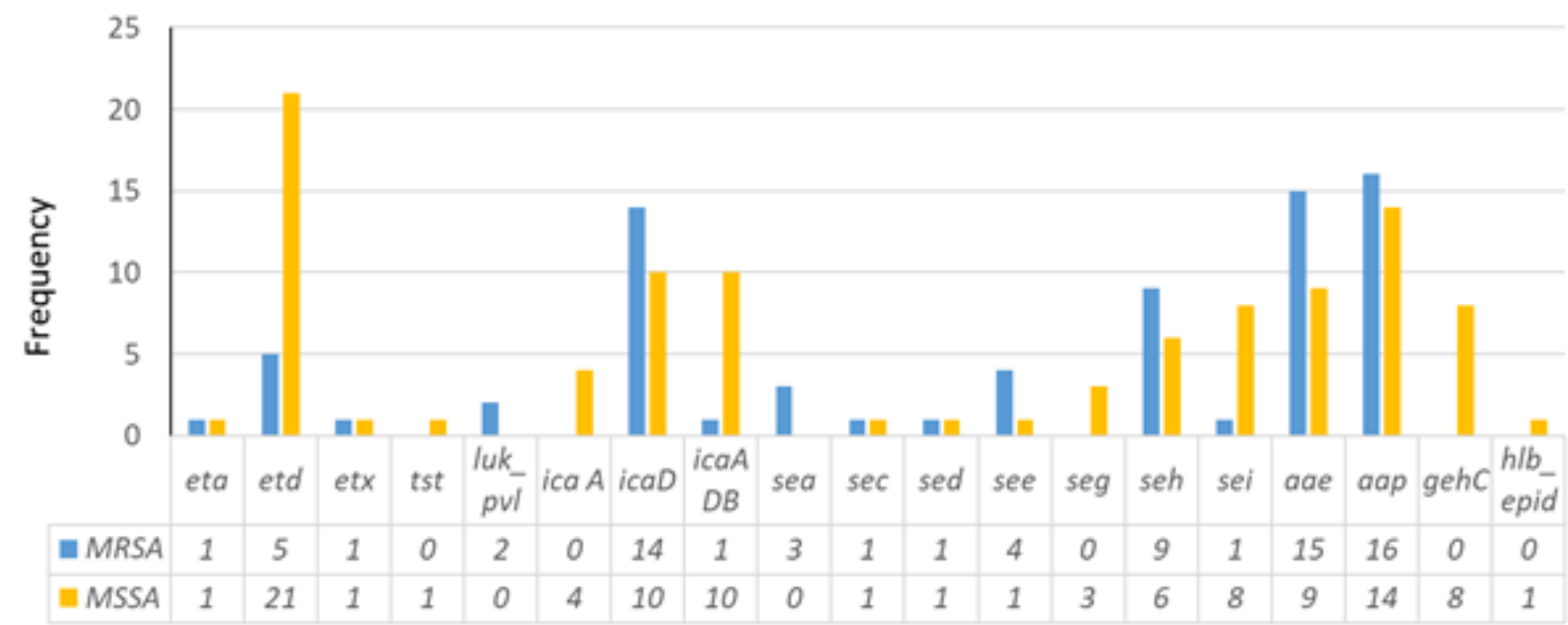

Figure 2: Frequency of virulence genes among MRSA and MSSA isolates. eta, exfoliative toxin A; etd, exfoliative toxin $\mathrm{D}$; etx, exfoliative toxin $X$; tsst-1, toxic shock syndrome toxin-1; luk_pvl, Panton-valentine leukocidin; ica $A$, intercellular adhesion $A$; icaD, intercellular adhesion $\mathrm{D}$; ica $A D B$, intercellular adhesion ADB; sea, staphylococcal enterotoxin A; sec, staphylococcal enterotoxin $\mathrm{C}$; sed, staphylococcal enterotoxin $\mathrm{D}$; see, staphylococcal enterotoxin $\mathrm{E}$; seg, staphylococcal enterotoxin $\mathrm{G}$; seh, staphylococcal enterotoxin $\mathrm{H}$; sei, staphylococcal enterotoxin I; aae, autolysin $A$; aap, accumulation-association proteins; gehC, triacylglycerol lipase C; hlb_epid, beta hemolysin.

with similar studies from Iran (Alfatemi et al., 2014), Germany (Becker et al., 1998) and Columbia (Smyth and Kahlmeter, 2005) which reported the frequency rates of eta gene as $0.68 \%, 2 \%$ and $3 \%$, respectively.

The tsst-1 gene was only detected in one MRSA isolates $(2.08 \%)$ in our study. Our result contravenes with the study in Iran (Koosha et al., 2016), which reported a high frequency of tsst-1 gene among MRSA (69.8\%) and MSSA (56.0\%) in 172 wound isolates. The frequency of luk pvl was reported in Tehran $24.2 \%$ (Norouzi et al., 2012), Isfahan 75\% (Ohadian-Moghadam et al., 2012) and Columbia $73 \%$ (Ertas et al., 2010). The frequency of luk pvl gene in our study was $4.17 \%$. The frequency obtained in our study is similar to the study in Iran, which reported the frequency of $p v /$ gene to be $5.47 \%$ (Alfatemi et al., 2014). These differences may be due to the geographical differences in the isolated genotypes of the MRSA and MSSA strains included in the study.

Hemolysins are important virulence factors contributing to Staphylococcal infections. Phenotypically, we accessed the presence or absence of hemolysis among the MRSA and MSSA isolates based on the hemolytic zone area produced. From the 23 MRSA isolates examined, $10 \quad(43.5 \%)$ isolates showed hemolysis, whilst $13(56.5 \%)$ did not show any hemolysis. As for MSSA isolates, $15(60.0 \%)$ isolates exhibited hemolysis, whilst $10(40.0 \%)$ MSSA isolates did not produce any hemolysis. However, our results showed the absence of hla haem and hld epid genes in all the isolates tested. The absence of these genes is in contrary to the study conducted in Iran (Motamedi et al., 2018), which reported the presence of hemolysin genes ( $h / a, h / b$, $h / d$ and $h / g$ ) among 389 clinical MRSA isolates as $9.19 \%$, $8.04 \%, 13.79 \%$ and $3.44 \%$ respectively. Although we could not find any genetic determinant that we investigated by PCR, our results may indicate the presence of other hemolysis gene(s) among these isolates (Figure 1).

Despite evaluation of limited number of strains from a single center, our study showed the importance of biofilm associated virulence genes (icaD, ica $A D B$ ) in contributing to diabetic foot infections. The virulence genes were more diverse and abundant in MSSA than in MRSA strains as shown in Figure 2.

\section{CONCLUSION}

In conclusion, we found that the genes that encode for proteins related to the production and formation of biofilms (aap) are remarkably significant among MRSA and MSSA strains. Interestingly, an exfoliative gene (etd) was also found in high frequency among the diabetic isolates studied. This may be related to their proinflammatory effects. Despite the importance of hemolysins in $S$. aureus infections, our findings did not indicate the presence of hla_haem and hld_epid genes among the MRSA and MSSA isolates tested.

\section{ETHICAL APPROVAL}

As the testing used in this study is only a laboratory procedure done on specimens obtained for clinical purposes, there was no need for ethical approval.

\section{INFORMED CONSENT}

Patients were treated by their physicians according to standard protocols. As no additional specimens were collected for the virulence testing, and their identity was not linked in this publication to any identifying features, 
we did not need to obtain informed consent for this testing.

\section{ACKNOWLEDGEMENTS}

This project was funded by Aydin Adnan Menderes University BAP with project number (REDPROM 20001).

\section{REFERENCES}

Aggarwal, S., Jena, S., Panda, S., Sharma, S., Dhawan, B., Nath, G., Singh, N. P., Nayak, K. C. and Singh, D. V. (2019). Antibiotic susceptibility, virulence pattern, and typing of Staphylococcus aureus strains isolated from variety of infections in India. Frontiers in Microbiology 10, 2763.

Alfatemi, S. M. H., Motamedifar, M., Hadi, N. and Saraie, H. S. E. (2014). Analysis of virulence genes among methicillin-resistant Staphylococcus aureus (MRSA) strains. Jundishapur Journal of Microbiology 7(6), e10741.

Amagai, M., Nishifuji, K., Yamaguchi, T., Hanakawa, Y., Sugai, M. and Stanley, J. R. (2002). Staphylococcal exfoliative toxin B specifically cleaves desmoglein 1. Journal Investigative Dermatology 118(5), 845-850.

Arciola, C. R., Campoccia, D., Gamberini, S., Donati, M. E. and Montanaro, L. (2004). Presence of fibrinogen-binding adhesin gene in Staphylococcus epidermidis isolates from central venous cathetersassociated and orthopaedic implant-associated infections. Biomaterials 25(19), 4825-4829.

Arciola, C. R., Gamberini, S., Campoccia, D., Visai, L., Speziale, P., Baldassarri, L. and Montanaro, L. (2005). A multiplex PCR method for the detection of all five individual genes of ica locus in Staphylococcus epidermidis. A survey on 400 clinical isolates from prosthesis-associated infections. Journal of Biomedical Materials Research 75(2), 408-413.

Becker, K., Roth, R. and Peters, G. (1998). Rapid and specific detection of toxigenic Staphylococcus aureus: Use of two multiplex PCR enzyme immunoassays for amplification and hybridization of staphylococcal enterotoxin genes, exfoliative toxin genes, and toxic shock syndrome toxin-1 gene. Journal of Clinical Microbiology 36(9), 2548-2553.

Bergdoll, M. S., Borja, C. R., Robbins, R. N. and Weiss, K. F. (1971). Identification of enterotoxin E. Infection and Immunity 4(5), 593-595.

Bergdoll, M. S., Crass, B. A., Reiser, R. F., Robbins, R. N. and Davis, J. P. (1981). A new staphylococcal enterotoxin, enterotoxin $F$, associated with toxic-shock syndrome Staphylococcus aureus isolates. The Lancet 317(8228), 1017-1021.

Bowden, M. G., Visai, L., Longshaw, C. M., Holland, K. T., Speziale, P. and Hook, M. (2002). Is the GehD lipase from Staphylococcus epidermidis a collagen binding adhesin? The Journal of Biological Chemistry 277(45), 43017-23.
Conlon, B. P., Geoghegan, J. A., Waters, E. M., McCarthy, H., Rowe, S. E., Davies, J. R., Schaeffer, C. R., Foster, T. J., Fey, P. D. and O'Gara, J. P. (2014). Role for the A domain of unprocessed accumulation-associated protein (Aap) in the attachment phase of the Staphylococcus epidermidis biofilm phenotype. Journal of Bacteriology 196 (24), 4268-4275.

Costerton, J. W., Stewart, P. S. and Greenberg, E. P. (1999). Bacterial biofilms: A common cause of persistent infections. Science 284(5418), 1318-1322.

Cramton, S. E., Gerke, C., Schnell, N. F., Nichols, W. W. and Götz, F. (1999). The intercellular-adhesion (ica) locus is present in Staphylococcus aureus and is required for biofilm formation. Infection and Immunity 67(10), 5427-5433.

Diekema, D. J., Pfaller, M. A., Schmitz, F. J., Smayevsky, J., Bell, J., Jones, R. N., Beach, M. and SENTRY partcipants group. (2001). Survey of infections due to Staphylococcus species: Frequency of occurrence and antimicrobial susceptibility of isolates collected in the United States, Canada, Latin America, Europe, and the Western Pacific region for the SENTRY Antimicrobial Surveillance Program, 1997-1999. Clinical Infectious Disease 32 (Suppl 2), S114-S132.

Dunyach-Remy, C., Essebe, C. N., Sotto, A. and Lavigne, J. (2016). Staphylococcus aureus toxins and diabetic foot ulcers: Role in pathogenesis and interest in diagnosis. Toxins 8(7), 209.

Ertas, N., Gonulalan, Z., Yildirim, Y. and Kum, E. (2010). Detection of Staphylococcus aureus enterotoxins in sheep cheese and dairy desserts by multiplex PCR technique. International Journal of Food Microbiology 142(1-2), 74-77.

Freer, J. H. and Arbuthnott, J. P. (1982). Toxins of Staphylococcus aureus. Pharmacology and Therapeutics 19(1), 55-106.

Ghasemian, A. Peerayeh, S. N., Bakhshi, B. and Mirzaee, M. (2016). Comparison of biofilm formation between methicillin-resistant and methicillinsusceptible isolates of Staphylococcus aureus. Iran Biomedical Journal 20(3), 175-181.

Guo, Y., Ding, Y., Liu, L., Shen, X., Hao, Z., Duan, J., Jin, Y., Chen, Z. and Yu, F. (2019). Antimicrobial susceptibility, virulence determinants profiles and molecular characteristics of Staphylococcus epidermidis isolates in Wenzhou, eastern China. BMC Microbiology 19, 157.

Hatipoglu, M., Mutluoglu, M., Uzun, G., Karabacak, E., Turhan, V. and Lipsky, B. A. (2014). The microbiologic profile of diabetic foot infections in Turkey: A 20-year systematic review: Diabetic foot infections in Turkey. European Journal of Clinical Microbiology and Infectious Disease 33(6), 871-878.

Heilmann, C., Thumm, G., Chhatwal, G. S., Hartleib, J., Uekötter, A. and Peters, G. (2003). Identification and characterization of a novel autolysin (Aae) with adhesive properties from Staphylococcus epidermidis. Microbiology 149(10), 2769-2778. 
Johnson, W. M., Tyler, S. D., Ewan, F. E., Ashton, F. E., Pollard, D. R. and Rozee, K. R. (1991). Detection of genes for enterotoxins, exfoliative toxins, and toxicshock syndrome syndrome toxin 1 in Staphylococcus aureus by the polymerase chain reaction. Journal of Clinical Microbiology 29(3), 426-430.

Jørgensen, H. J., Mathisen, T. Løvseth, A., Omoe, K., Qvale, K. S. and Loncarevic, S. (2005). An outbreak of staphylococcal food poisoning caused by enterotoxin $\mathrm{H}$ in mashed potato made with raw milk. FEMS Microbiology Letters 252(2), 267-272.

Kamarehei, F., Ghaemi, E. A. and Dadgar, T. (2013). Prevalence of enterotoxin A and B genes in Staphylococcus aureus isolated from clinical samples and healthy carriers in Gorgan City, North of Iran. Indian Journal of Pathology and Microbiology 56(3), 265-268.

Katayama, Y., Ito, T. and Hiramatsu, K. (2000). A new class of genetic element, staphylococcus cassette chromosome mec, encodes methicillin-resistance in Staphylococcus aureus. Antimicrobial Agents and Chemotherapy 44(6), 1549-1555.

Koosha, R. Z., Hosseini, H. M., Aghdam, E. M., Tajandareh, S. G. and Fooladi, A. A. I. (2016). Distribution of tsst-1 and mecA genes in Staphylococcus aureus isolated from clinical specimens. Jundishapur Journal of Microbiology 9(3), e29057.

Liesse lyamba, J. M., Seil, M., Devleeschouwer, M., Takaisi Kikuni, N. B. and Dehaye, J. P. (2011). Study of the formation of a biofilm by clinical strains of Staphylococcus aureus. Biofouling 27(8), 811-821.

Lina, G., Piémon, Y., Godail-Gamot, F., Bes, M., Peter, M. O., Gauduchon, V., Vandenesch, F. and Etienne, J. (1999). Involvement of Panton-Valentine leukocidin-producing Staphylococcus aureus in primary skin infections and pneumonia. Clinical Infectious Diseases 29(5), 1128-1132.

Lipsky, B. A., Aragón-Sánchez, J., Diggle, M., Embil, J., Kono, S., Lavery, L., Senneville, É., UrbančičRovan, V., Van Asten, S. and Peters, E. J. G. (2016). IWGDE guidance on the diagnosis and management of foot infections in persons with diabetes. Diabetes/Metabolism Research and Reviews 32(Suppl 1), 45-74.

Liu, C., Chen, Z., Sun, Z., Feng, X., Zou, M., Cao, W., Wang, S., Zeng, J., Wang, Y. and Sun, M. (2015). Molecular characteristics and virulence factors in methicillin-susceptible, resistance and heterogeneous vancomycin-intermediate Staphylococcus aureus from central-southern china. Journal of Microbiology, Immunology and Infection 48(5), 490-496.

Mariutti, R. B., Tartaglia, N. R., Seyffert, N., de Paula Castro, T. L., Arni, R. K., Azevedo, V. A., Le Loir, Y. and Nishifuji, K. (2017). Exfoliative toxins of Staphylococcus aureus. In: The rise of virulence and antibiotic resistance in Staphylococcus aureus. Enany, S. and Alexander, L. E. C. (eds.). Intech Open, London, UK. pp. 127-144.
Mashouf, R. Y., Hosseini, S. M., Mousavi, S. M. and Arabestani, M. R. (2015). Prevalence of enterotoxin genes and antibacterial susceptibility pattern of Staphylococcus aureus strains isolated from animal originated foods in West of Iran. Oman Medical Journal 30(4), 283-290.

Mehrotra, M., Wang, G. and Johnson, W. M. (2000). Multiplex PCR for detection of genes for Staphylococcus aureus enterotoxins, exfoliative toxins, toxic shock syndrome toxin 1, and methicillin resistance. Journal of Clinical Microbiology 38(3), 1032-1035.

Moore, P. C. and Lindsay, J. A. (2001). Genetic variation among hospital isolates of methicillinsensitive Staphylococcus aureus: Evidence for horizontal transfer of virulence genes. Journal of Clinical Microbiology 39(8), 2760-2767.

Motamedi, H., Asghari, B., Tahmasebi, H. and Arabestani, M. R. (2018). Identification of hemolysin genes and their association with antimicrobial resistance pattern among clinical isolates of Staphylococcus aureus in West of Iran. Advanced Biomedical Research 7, 153.

Norouzi, J., Goudarzi, G., Pakzad, P. and Razavipour, R. (2012). The isolation and detection of Staphylococcus aureus enterotoxins A-E and tsst-1 genes from different sources by PCR method. Journal of QOM University of Medical Sciences Journal 6(3), 78-85.

O'Neill, E., Pozzi, C., Houston, P., Smyth, D., Humphreys, H., Robinson, D. A. and O'Gara, J. P. (2007). Association between methicillin susceptibility and biofilm regulation in Staphylococcus aureus isolates from device-related infections. Journal of Clinical Microbiology 45(5), 1379-1388.

Ohadian, M. S., Pourmand, M. R. and Aminharati, F. (2014). Biofilm formation and antimicrobial resistance in methicillin-resistant Staphylococcus aureus isolated from burn patients, Iran. Journal of Infection in Developing Countries 8(12), 1511-1517.

Ohadian-Moghadam, S. Havaei, S. A. and Pourmand, M. R. (2012). Prevalence of methicillin-resistant Staphylococcus aureus carrying Panton-Valentine leukocidin gene in cutaneous infections in the City of Isfahan. Journal of Medical Bacteriology 1(1-2), 9-16.

Omoe, K., Ishikawa, M., Shimoda, Y., Hu, D. Ueda, S. and Shinagawa, K. (2002). Detection of seg, seh, and sei genes in Staphylococcus aureus isolates and determination of the enterotoxin productivities of $S$. aureus isolates harbouring seg, seh, or sei genes. Journal of Clinical Microbiology 40(3), 857-862.

Peacock, S. J., Moore, C. E., Justice, A., Kantzanou, M., Story, I., Mackie, K., O'Neill, G. and Day, N. P. J. (2002). Virulent combinations of adhesin and toxin genes in natural populations of Staphylococcus aureus. Infection and Immunity 70(9), 4987-4996.

Prévost, G., Mourey, L., Colin, D. A. and Menestrina, G. (2001). Staphylococcal pore-forming toxins. Current Topics in Microbiology and Immunology 257, 53-83. 
Richard, J. L., Lavigne, J. P., Got, I., Hartemann, A., Malgrange, D., Tsirtsikolou, D., Baleydier, A. and Senneville, E. (2011). Management of patients hospitalized for diabetic foot infection: Results of the French OPIDIA study. Diabetes and Metabolism 37(3), 208-215.

Rosec, J. P. and Gigaud, O. (2002). Staphylococcal enterotoxin genes of classical and new types detected by PCR in France. International Journal of Food Microbiology 77(1-2), 61-70.

Salgueiro, V. C., lorio, N. L. P., Ferreira, M. C., Chamon, R. C. and dos Santos, K. R. N. (2017). Methicillin-resistance and virulence genes in invasive and nasal Staphylococcus epidermidis isolates from neonates. BMC Microbiology 17, 15.

Schaeffer, C. R., Woods, K. M., Longo, G. M., Kiedrowski, M. R., Paharik, A. E., Büttner, H. Christner, M., Boissy, R. J., Horswill, A. R., Rohde, H. and Fey, P. D. (2015). Accumulation-associated protein enhances Staphylococcus epidermidis biofilm formation under dynamic conditions and is required for infection in a rat catheter model. Infection and Immunity 83(1), 214-226.

Schito, G. C. (2006). The importance of the development of antibiotic resistance in Staphylococcus aureus. Clinical Microbiology and Infection 12(Suppl 1), 3-8.

Seier-Petersen, M. A., Nielsen, L. N., Ingmer, H., Aarestrup, F. M. and Agersø, Y. (2015). Biocide susceptibility of Staphylococcus aureus CC398 and CC30 isolates from pigs and identification of the biocide resistance genes, qacG and qacC. Microbial Drug Resistance 21(5), 527-536.

Sila, J., Sauer, P. and Kolar, M. (2009). Comparison of the prevalence of genes coding for enterotoxins, exfoliatins, panton-valentine leukocidin and tsst-1 between methicillin-resistant and methicillinsusceptible isolates of Staphylococcus aureus at the university hospital in Olomouc. Biomedical Papers of the Medical Faculty of the University Palacky, Olomouc, Czechoslovakia 153(3), 215-218.

Smith, K., Perez, A., Ramage, G., Lappin, D., Gemmell, C. G. and Lang, S. (2008). Biofilm formation by Scottish clinical isolates of Staphylococcus aureus. Journal of Medical Microbiology 57(8), 1018-1023.

Smyth, R. W. and Kahlmeter, G. (2005). Mannitol salt agar-cefoxitin combination as a screening medium for methicillin-resistant Staphylococcus aureus. Journal of Clinical Microbiology 43(8), 3797-3799.

Sotto, A., Lina, G., Richard, J., Combescure, C., Bourg, G., Vidal, L., Jourdan, N., Etienne, J. and Lavigne, J. (2008). Virulence potential of Staphylococcus aureus strains isolated from diabetic foot ulcers: A new paradigm. Diabetes Care 31(12), 2318-2324.

Spichler, A., Hurwitz, B. L., Armstrong, D. G. and Lipsky, B. A. (2015). Microbiology of diabetic foot infections: From Louis Pasteur to 'crime scene investigation'. BMC Medicine 13, 2.
Stepanović, S., Vuković, D., Hola, V., Di Bonaventura, G., Djukić, S., Cirković, I. and Ruzicka, F. (2007). Quantification of biofilm in microtiter plates: Overview of testing conditions and practical recommendations for assessment of biofilm production by staphylococci. Acta Pathologica, Microbiologica, et Immunologica Scandinavica 115(8), 891-899.

Vandecasteele, S. J., Peetermans, W. E., Merckx, R. R., Rijnders, B. J. A. and Van Eldere, J. (2003). Reliability of the ica, aap and at/E genes in the discrimination between invasive, colonizing and contaminant Staphylococcus epidermidis isolates in the diagnosis of catheter-related infections. Clinical Microbiology and Infection 9(2), 114-119.

Víquez-Molina, G., Aragón-Sánchez, J., PérezCorrales, C., Murillo-Vargas, C., López-Valverde, M. E. and Lipsky, B. A. (2018). Virulence factor genes in Staphylococcus aureus isolated from diabetic foot soft tissue and bone infections. The International Journal of Lower Extremity Wounds 17(1), 36-41.

Wolk, D. M., Struelens, M. J., Pancholi, P., Davis, T., Della-Latta, P., Fuller, D., Picton, E., Dickenson, R., Denis, O., Johnson, D. and Chapin, K. (2009). Rapid detection of Staphylococcus aureus and methicillin-resistant $S$. aureus (MRSA) in wound specimens and blood cultures: Multicenter preclinical evaluation of the Cepheid Xpert MRSA/SA skin and soft tissue and blood culture assays. Journal of Clinical Microbiology 47(3), 823-826.

Wu, D., Li, X., Yang, Y., Zheng, Y., Wang, C., Deng, L., Liu, L., Li. C., Shang, Y., Zhao, C., Yu, S. and Shen, X. (2011). Superantigen gene profiles and presence of exfoliative toxin genes in community-acquired meticillin-resistant Staphylococcus aureus isolated from Chinese children. Journal of Medical Microbiology 60(1), 35-45. 